\title{
Den interpersonlige teorien om selvmord
}

\author{
Av Johan Siqveland
}

\section{SAMMENDRAG}

Den interpersonlige teorien om selvmord (ITS) er en relativt ny modell for selvmordsatferd som allerede i løpet av vel ti år har generert en betydelig mengde forskning. ITS er en modell for selvmordsatferd som bygger på at selvmord og alvorlig selvskade kan forklares gjennom samspillet mellom tre faktorer. To av faktorene, opplevelsen av å være en byrde for andre og manglende tilhørighet, forklarer hvordan selvmordstanker oppstår. Den tredje faktoren forklarer hvorfor bare et fåtall av de som har selvmordstanker dør av selvmord. Å skade seg alvorlig utløser en beskyttende sterk frykt, og bare de med en oppøvd evne til å skade seg selv alvorlig kan overkomme den, ifølge denne teorien. Det er når manglende tilhørighet, opplevelse av å være en byrde og evne til alvorlig selvskade er sterkt til stede samtidig, at personer kan dø av selvmord. Denne artikkelen vil presentere ITS-modellen, gjennomgå empirisk forskning om modellen og presentere kliniske implikasjoner.

The interpersonal theory of suicide (ITS) is a fairly new model of suicidal behavior which has generated a substantial amount of empirical research over the past 10 years. According to the ITS, suicide and severe self-injury can best be understood as an interplay between three factors. The interplay between two of these factors, thwarted belongingness and perceived burdensomeness, explains why people develop suicidal ideation. The third factor explains why only a minority of those with suicidal ideation die by suicide. To injure oneself severely or to kill oneself causes a natural and protective immense fear. To pass this threshold, a capacity for severe self-injury is necessary, according to this theory. When thwarted belongingness, perceived burdensomeness and acquired capability of serious self-injury are present at the same time, the risk of dying by suicide is highest, according to the theory. This article will present the ITS and review empirical research on the theory. Lastly, clinical implications will be presented.

THOMAS JOINER, professor i psykologi ved Florida State University, starter boken Why people die by suicide med spørsmålet «Hvorfor dør mennesker av selvmord?» (Joiner 2005). Resten av boken forsøker å svare på dette spørsmålet. Joiner hevder i denne boken at det er to spesielt viktige faktorer som er til stede hos mennesker som kan dø av selvmord; de har et ønske om å dø og en oppøvd evne til å skade seg selv alvorlig nok til at de dør. Đnsket om å dø, sier Ioiner videre, kommer av at personen kjenner seg som en byrde for og ikke føler noen tilhørighet til andre mennesker. Denne teorien er en modell for selvmordsatferd med få faktorer som gir grunnlag for hypoteser som kan testes empirisk. Teorien har gitt grunnlag for empirisk forskning og blitt testet i stadig flere ulike land, og med ulike forskningsmetoder.

ITS er en sosial kognitiv teori som bygger på tidligere psykologiske teorier om hvordan tilfredsstillelse av grunnleggende psykologiske behov er nødvendig for god psykisk helse. Teorien har mange fellestrekk med for eksempel Self-determination theory (Deci \& Ryan, 2008; Hill \& Pettit, 2013), som er en mer generell teori om psykisk helse og velvære. Begge teoriene vektlegger behovet for å kjenne seg mestrende og autonom i eget liv, og ITS er således knyttet til andre og mer generelle teorier om psykisk helse. Ved at ITS vektlegger manglende oppfyllelse av psykologiske behov som bakgrunn eller årsak til selvmordstanker, representerer den et alternativ til modeller basert på psykiatriske diagnoser som mest nærliggende årsak for selvmord (Hawton \& 
van Heeringen, 2009). Joiner avviser imidlertid ikke at psykiske lidelser allikevel er viktige risikofaktor for selvmord. Det han hevder er at psykiske lidelser, forst og fremst depresion, er forbundet med selvmord fordi depresion svekker grunnleggende psykiske behov. Dette flytter forståelsen av selvmordet fra psykopatologi til allmennpsykologi, noe som kan gi en mulighet til bedre å forstå og forebygge selvmord også hos personer uten psykiske lidelser (Ribeiro et al., 2017).

\section{Modellen for selvmordstanker og selvmord}

ITS hevder altså at tre faktorer er de mest nærliggende for selvmordstanker og alvorlige selvmordsforsøk.
To av faktorene forklarer hvem som utvikler selvmordstanker, mens den siste faktoren forklarer hvem med selvmordstanker som dør av selvmord. Faktorene samspiller på viktige måter, slik at det er når de alle tre er til stede samtidig at det er størst fare for selvmord.

Den ene utløsende faktoren for selvmordstanker er opplevelsen av å mangle tilhørighet, mangle viktige sosiale relasjoner og føle at en ikke tilhører noe fellesskap som oppleves viktig. Ensomhet, sosial isolasjon eller sosial disintegrasion har lenge vært ansett som viktig for å forstå selvmord helt fra en av de første teoriene om selvmord (Durkheim, 1897). Manglende tilhørighet kan måles giennom spørsmål som «Nå

Figur 1. Konseptuell modell av den interpersonlige teorien om selvmord (oversatt fra Van Orden, Smith, Chen, \& Conwell, 2016).

Bakenforliggende risikofaktorer for selvmord
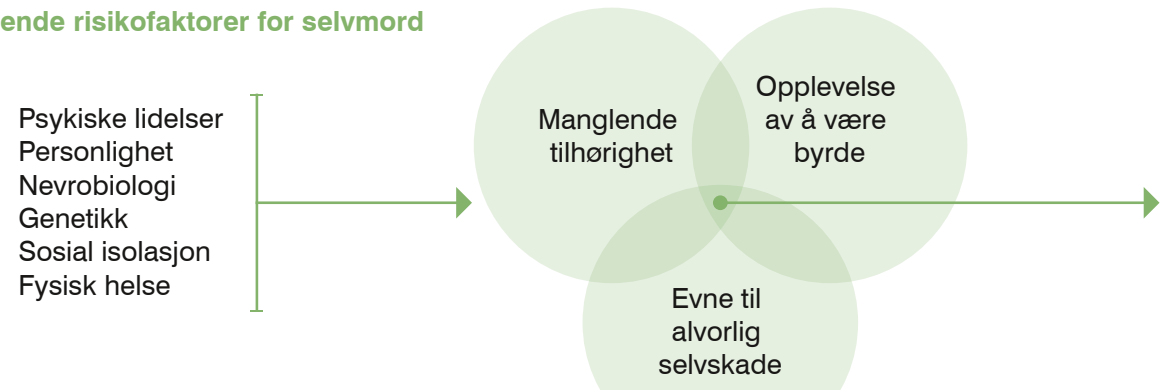

Selvmord 
for tiden er det ingen som bryr seg om meg». Denne opplevelsen av sosial isolasjon er så viktig fordi den representerer grunnleggende sosiale motiver og behov hos mennesker (Van Orden et al., 2010).

Manglende tilhørighet kan forklare sosiodemografiske forskjeller i selvmord. For eksempel har menn, som ofte er dårligere til å ivareta sosiale relasjoner enn kvinner, den høyeste selvmordsrisikoen. Et annet eksempel er at selvmordstanker er mest vanlige hos studenter like etter at de har flyttet til studiestedet, og dermed har mindre kontakt med familien og har få venner eller personer de kjenner godt (Servaty-Seib, Lockman, Shemwell, \& Reid Marks, 2016).

Den andre utløsende faktoren for selvmordstanker er å oppleve seg som en byrde. Å oppleve seg som en byrde og å mangle tilhørighet er relaterte, men allikevel forskjellige begreper. Opplevelsen av å være en byrde for andre er tanken om at andre vil få det bedre uten meg. Personen tenker at «for andre rundt meg er det bedre at jeg er død enn at jeg lever». Opplevelsen av å være en byrde kan måles giennom spørsmål som «leg føler at jeg har sviktet andre mennesker i livet mitt» og «Andre rundt meg ville

Et av de mer spekulative elementene i ITS er at tanker om selvmord og selvtilintetgiørelse er et nedarvet instinkt fra tiden da menneskene var sankere og levde $i$ nomadiske flokker. hatt det bedre uten meg». Et av de mer spekulative elementene i ITS er at tanker om selvmord og selvtilintetgiørelse er et nedarvet instinkt fra tiden da menneskene var sankere og levde i nomadiske flokker. Dette instinktet førte til at personer kunne ofre livet sitt for ikke å sinke flokken ved neste flytting. Sammenhengen mellom opplevelsen av å være en byrde og ha selvmords-

tanker har blitt undersøkt i flere ulike grupper, og flere studier har funnet at denne følelsen medierer sammenhengen mellom depresion og selvmordstanker blant eldre mennesker (Cukrowicz, Cheavens, Van Orden, Ragain, \& Cook, 2011).

Noen forskere har foreslått at tilstedeværelsen av enten manglende tilhørighet eller opplevelse av å være en byrde er knyttet til passive selvmordstanker (tanker om døden uten konkrete planer) mens tilstedeværelsen av begge faktorene er knyttet til aktive selvmordstanker og konkrete selvmordsplaner (Cero, Zuromski, Witte, Ribeiro, \& Joiner, 2015).

Det tredje elementet i ITS, evne til alvorlig selvskade, er viktig fordi et onske om døden i seg selv ikke er tilstrekkelig for alvorlige selvmordsforsøk. Mennesker er fra naturens side beskyttet mot å tilintetgiøre seg selv giennom en sterk frykt for døden, og vil naturlig forsøke å unngå å skade seg selv. Evne til å håndtere frykten og den mentale og fysiske smerten ved å skade seg selv alvorlig er ikke medfødt, men oppøvd giennom ulike smertefulle opplevelser. Denne evnen kalles oppovd evne til alvorlig selvskade, og utvikles giennom eksponering for ulike smertefulle hendelser. Tidligere selvmordsforsøk er den aller viktigste opplevelsen, med mest effekt for å øke evne til dødelig selvskade, men også andre opplevelser har betydning, som seksuelle overgrep og yrkeserfaringer som helsepersonell eller soldat. Felles for disse opplevelsene er at personen tidligere har blitt eksponert for fryktskapende situasioner, oppøvd toleranse for smerte og frykt, og bryte ned den naturlige beskyttelsen mot alvorlig selvskade. Oppøvd evne til alvorlig selvskade kan forklare kjente sammenhenger mellom tidligere opplevelser og selvmord. Det viktigste er sammenhengen med tidligere selvmordsforsøk. Tidligere erfaring med selvskading er blant de viktigste risikofaktorene for senere selvmord, men denne teorien gir en bedre forståelse for hvorfor det er en sterk sammenheng mellom selvskading og tidligere selvmordsforsøk og selvmord (Suominen et al., 2004).

Ingen av elementene i ITS er unike, og lignende temaer har blitt foreslått som utløsende for selvmord i andre teorier. For eksempel har ITS mange felles punkter med modeller for selvmord som legger vekt på depresion som utløsende for selvmord. Personer som er deprimerte vil også oppleve seg som mer isolerte, og mange kan oppleve at de er en byrde for andre. ITS foreslår at selv om depresion er relatert til selvmord er de viktigste faktorene for å forstå selvmord ikke depresjonen i seg selv, men at depresion svekker bånd til andre mennesker, og senker selvtillit og selvfølelse slik at man lett føler seg som en byrde for andre. De to interpersonlige elementene er altså mer nærliggende grunner for selvmord, forbundet med depresion, men allikevel noe annet enn depresjon, ifølge ITS.

Slik er faktorene bak selvmordstanker lignende innen ITS og modeller som beskriver depresjon som den mest nærliggende og utløsende faktoren for selvmord. Imidlertid vil bare $5 \%$ av de som en gang har vært innlagt på sykehus for behandling av depresion dø av selvmord (O'Connor \& Nock, 2014), og det er altså et behov for mer nøyaktige prediktive modeller for hvem blant dem som er deprimerte som vil kunne dø av selvmord.

\section{Forskning om ITS støtter i noen grad sentrale antagelser} ITS gir altså grunnlag for å lage testbare hypoteser som kan undersøkes empirisk og dette er noe av grunnlaget for teoriens popularitet. Imidlertid, selv om teorien gir forklaringer og prediksjoner om fullførte selvmord, er det meste av forskningen omkring ITS giennomført på andre utfallsmål, som selvmordsforsøk. Det er også langt mer forskning om betydningen av manglende tilhørighet og opplevd byrde for selvmordstanker, enn for hele modellen for alvorlige selvmordsfors $ø$, trolig fordi dette første er enklere hypoteser å teste. 
I tillegg til gyldigheten til hypoteser utledet fra ITS har også den grunnleggende teoretiske modellen med tre faktorer blitt undersøkt. En påstand i ITS er at manglende tilhørighet og opplevelse av å være en byrde er to relaterte, men allikevel adskilte begreper. Dette har bare delvis fått støtte, for eksempel fant en faktoranalyse av skalaene som måler manglende tilhørighet og opplevd byrde at begrepene best kan beskrives psykometrisk som én faktor og ikke to atskilte begreper (Christensen, Batterham, Mackinnon, Donker, \& Soubelet, 2014).

Den nyeste systematiske oversikten over ITS-forskning inkluderte 66 sammenligninger fra 58 ulike studier (Ma, Batterham, Calear, \& Han, 2016). Oversikten viste at både de direkte effektene av opplevd byrde og manglende tilhørighet på selvmordstanker, effekten av oppøvd evne til alvorlig selvskade på alvorlige selvmordsforsøk, samt interaksjoner mellom disse faktorene var blitt undersøkt i flere studier. Oversiktsartikkelen konkluderte med at den empiriske støtten for ITS er blandet. Det var mest evidens for at opplevd byrde er assosiert med selvmordstanker; her var 82,6 \% av resultatene i tråd med den hypotesen. Hypotesen om at manglende tilhørighet er relatert til selvmordstanker fikk langt mindre støtte; her var det bare $40 \%$ av de 55 inkluderte studiene som fant en signifikant sammenheng mellom manglende tilknytning og selvmordstanker. Sammenhengen mellom oppøvd evne til alvorlig selvskade og selvmordsforsøk var heller ikke konsistent. Blant de studiene som hadde undersøkt denne sammenhengen rapporterte $55 \%$ av studiene en signifikant sammenheng. Svakheten med denne oversikten var at den ikke giorde en kvantitativ sammenfatning av dataene giennom en metaanalyse, og heller ikke graderte forskningskvaliteten bak funnene i de inkluderte studiene. De fleste av de inkluderte studiene var små og hadde lav statistisk styrke. Dermed er usikkerheten større omkring gyldigheten av disse oppsummerte resultatene. Sammenhengen mellom de teoretiske begrepene i ITS og selvmordsatferd kan dermed være både sterkere og svakere enn det som kommer frem i den systematiske oversikten.

Oppsummert synes forskning altså ikke entydig å støtte de predikerte sammenhengene mellom manglende tilhørighet, opplevelse av å være en byrde og selvmordstanker og selvmordsatferd, slik som de er predikert av ITS. Det er manglende støtte både for grunnmodellen at manglende tilhørighet og opplevd byrde virkelig er to ulike begreper, og at det er en konsistent signifikant sammenheng mellom faktorene i modellen og selvmordstanker og selvmordsforsøk.

\section{Betydning av ITS for behandling og forebygging av selvmord}

Det er flere kliniske intervensjoner som følger av ITS (Joiner \& Van Orden 2008). En av de få intervensjonene som har vist en sikker effekt i reduksjon av selvmordsatferd er i tråd med sentrale prediksjoner fra ITS. En randomisert studie inkluderte personer som nylig hadde giort et selvmordsforsøk og var vurdert til å ha høy risiko for nye selvmordsforsøk, men som ikke ønsket annen oppfølging. Et tilfeldig utvalg av disse pasientene fikk tilsendt et brev fra sykehuset hvor det stod at de håpet at personen hadde det bra, men var velkommen til å ta kontakt om de trengte hielp. De fant at i gruppen som fikk disse brevene var det færre som ble lagt inn igien etter nye selvmordsforsøk, enn det var i gruppen som ikke fikk brev (Motto \& Bostrom, 2001). Denne studien har senere blitt replikert i ulike former (Luxton et al., 2012; Luxton, June, \& Comtois, 2013) og viser betydningen av intervensjoner som fremmer tilhørighet og følelsen av at andre bryr seg om en.

ITS gir på flere måter støtte for at relasjoner er viktig for utfallet av psykoterapi med personer som er selvmordstruede. Det ene er å vektlegge relasjonen $i$ terapi, at terapien er et viktig prosiekt som terapeuten og pasienten har sammen. Hvordan relasionen mellom pasient og terapeut utvikler seg, og hvordan skader på relasjonen mellom dem kan la seg reparere, bør være en rollemodell som forsøkes generalisert til andre relasjoner i pasientens liv. Strukturereringer av terapien for å vektlegge relasjon bør vurderes. For eksempel kan David Jobes tilnærming til psykoterapi med selvmordstruede personer, Collaborative Assessment and Management of Suicidality (CAMS) (Jobes, 20o9), være nyttig. CAMS-terapier vektlegger å skape en relasjon mellom terapeut og pasient hvor de sammen utforsker pasientens suicidale onske og hvordan det trygt kan reduseres. Klinikere bør også alltid jobbe med å fremme pasientens relasjoner til andre viktige personer i pasientens liv, giennom å bidra til å løse konflikter, reparere emosjonelle bånd eller gi ideer til måter å knytte nye sosiale bånd. Også intervensioner hvor terapeuten arbeider for å redusere pasientens opplevelse av å være en byrde kan være viktige. En slik intervensjon kan for eksempel være en sokratisk utfordring av tankeinnhold. Hvordan kan for eksempel pasienten vite at andre vil ha det bedre uten hen? Hvordan kan pasienten finne ut om dette faktisk stemmer? Dette kan bidra til å skape større avstand til pasientens negative tankeinnhold om seg selv og få et mer realistisk bilde av hvilke tragiske konsekvenser selvmordet faktisk vil ha for andre.

Det siste elementet i teorien, oppøvd evne til alvorlig selvskade, er en mer stabil risikofaktor og ikke så lett å endre giennom terapi. Faktoren er kanskje viktigere i et teoretisk perspektiv og for statistisk beregning av risiko. Imidlertid kan en forståelse av oppøvd evne til alvorlig selvskade være nyttig for å planlegge sikringstiltak i løpet av terapien frem til selvmordsønsket er redusert og behovet for ekstra sikkerhet for pasienten blir mindre.

\section{Kritikk og oppsummering}

Som beskrevet tidligere har forskningen på ITS i vekslende grad støttet de sentrale prediksjonene fra ITS. ITS har også møtt andre ulike former for kritikk, både for fokuset begrepene i teorien innebærer, bort fra ubevisste 
konflikter og biologiske forhold, og for forskningsgrunnlaget for gyldigheten av hypoteser avledet fra teorien.

ITS kan kritiseres fordi teorien gir en mindre rolle til andre mulige viktige faktorer for selvmordsatferd, som biologiske forhold, og større sosiale forhold. Den individualiserer forståelsen av selvmord bort fra sosiale strukturer, som økonomisk ulikhet og diskriminering, og vektlegger individet sin unike persepsion av sin egen situasjon. Teorien gir, vil noen hevde, på tross av at begrepet «interpersonlig» antyder noe annet, for mye fokus på individuelle forklaringer på selvmord.

En risiko for skjevhet i ITS-forskningen er at det aller meste er giort av personer med et personlig engasjement i teorien. Det kan føre til skjevheter i forskningen grunnet «researcher allegiance» (Munder, Gerger, Trelle, \& Barth, 2011), altså for nære bånd mellom de som har utviklet teorien og de som forsker på den. Siden mye av forskningen om ITS har sprunget ut fra nære samarbeidspartnere til opphavsmannen til teorien, Thomas Joiner, kan resultater ha blitt tolket for positivt til å støtte teorien, mens negative funn som kunne ha svekket teorien har forblitt upubliserte. Mer nøytral forskning om gyldigheten av ITS er derfor ønskelig.

I sum har altså ITS i løpet av relativt kort tid generert en betydelig mengde forskning. Noen av de sentrale hypotesene fra teorien har fått støtte, og er lovende begreper å undersøke i videre forskning. Imidlertid er sammenhengen mellom begrepene fra ITS og selvmordsatferd ikke alltid blitt funnet, og der de er funnet er sammenhengen av relativt svak styrke. ITS kan trolig heller ikke forklare alle kompleksiteter og faktorer for selvmordsatferd. Det er vel heller ikke noe vi skal forvente av verken ITS eller noen andre modeller for selvmordsatferd, men summen av forskning indikerer at ITS kan være en nyttig modell i forståelsen av selvmordsatferd.

\section{Levert: 02.06.17 - Revidert: 27.09.17 - Godkjent: 02.10.17}

\section{REFERANSELISTE}

Cero, I., Zuromski, K. L., Witte, T. K., Ribeiro, I. D., \& Ioiner, T. E. (2015). Perceived burdensomeness, thwarted belongingness, and suicide ideation: Re-examination of the Interpersonal-Psychological Theory in two samples. Psychiatry Research, 228(3), 544-550. https://doi.org/10.1016/i.psychres.2015.05.055

Christensen, H., Batterham, P. I., Mackinnon, A. I., Donker, T., \& Soubelet, A. (2014). Predictors of the risk factors for suicide identified by the interpersonal-psychological theory of suicidal behaviour. Psychiatry Research, 219(2), 290-297. https://doi.org/10.1016/i.psychres.2014.05.029

Cukrowicz, K. C., Cheavens, I. S., Van Orden, K. A., Ragain, R. M., \& Cook, R. L. (2011). Perceived burdensomeness and suicide ideation in older adults. Psychology and Aging, 26(2), 331-338. https://doi.org/10.1037/a0021836

Deci, E. L., \& Ryan, R. M. (2008). Self-determination theory: A macrotheory of human motivation, development, and health. Canadian Psychology, 49(3), 182-185. https://doi.org/10.1037/a0012801

Hawton, K., \& van Heeringen, K. (2009). Suicide. The Lancet, 373(9672), 1372-1381. https://doi.org/10.1016/So140-6736(og)6o372-X
Hill, R. M., \& Pettit, I. W. (2013). The role of autonomy needs in suicidal ideation: integrating the interpersonal-psychological theory of suicide and self-determination theory. Archives of Suicide Research: Official Journal of the International Academy for Suicide Research, 17(August), 288-301. https://doi.org/10.1080/13811118.2013.777001

Jobes, D. A. (2009). CAMS-tilnærmingen til selvmordsrisiko: en filosofi og en klinisk tilnærming. Suicidologi, (1), 1-5.

Joiner, T. (2005). Why people die by suicide. Harvard University Press.

Ioiner, T. E., \& Van Orden, K. A. (2008). The Interpersonal-Psychological Theory of Suicidal Behavior Indicates Specific and Crucial Psychotherapeutic Targets. International Journal of Cognitive Therapy, 1(1), 80-89. https:// doi.org/10.1521/ijct.2008.1.1.80

Luxton, D. D., Iune, I. D., \& Comtois, K. A. (2013). Can postdischarge follow-up contacts prevent suicide and suicidal behavior? A Review of the Evidence. Crisis, 34(1), 32-41. https://doi.org/10.1027/0227-5910/a000158

Luxton, D. D., Kinn, I. T., June, I. D., Pierre, L. W., Reger, M. A., \& Gahm, G. A. (2012). Caring letters project: A military suicide-prevention pilot program. Crisis, 33(1), 5-12. https://doi.org/10.1027/0227-5910/a00oo93

Ma, I., Batterham, P. I., Calear, A. L., \& Han, I. (2016). A systematic review of the predictions of the Interpersonal-Psychological Theory of Suicidal Behavior. Clinical Psychology Review. https://doi.org/10.1016/i.cpr.2016.04.008

Motto, I. A., \& Bostrom, A. G. (2001). A randomized controlled trial of postcrisis suicide prevention. Psychiatric Services, 52(6), 828-833. https://doi. org/10.1176/appi.ps.52.6.828

Munder, T., Gerger, H., Trelle, S., \& Barth, I. (2011). Testing the allegiance bias hypothesis: A meta-analysis. Psychotherapy Research, 21(6), 670-684. https://doi.org/10.1080/10503307.2011.602752

O'Connor, R. C., \& Nock, M. K. (2014). The psychology of suicidal behaviour. The Lancet Psychiatry. https://doi.org/10.1016/S2215-0366(14)70222-6

Ribeiro, I. D., Gutierrez, P. M., Joiner, T. E., Kessler, R. C., Petukhova, M. V., Sampson, N. A., ... Nock, M. K. (2017). Health care contact and suicide risk documentation prior to suicide death: Results from the Army Study to Assess Risk and Resilience in Servicemembers (Army STARRS). Journal of Consulting and Clinical Psychology, 85(4), 403-408. https://doi.org/10.1037/ cсpoooo 178

Servaty-Seib, H. L., Lockman, I., Shemwell, D., \& Reid Marks, L. (2016). International and Domestic Students, Perceived Burdensomeness, Belongingness, and Suicidal Ideation. Suicide and Life-Threatening Behavior, 46(2), 141-153. https://doi.org/10.1111/sltb.12178

Suominen, K., Isometsä, E., Suokas, I., Haukka, I., Achte, K., \& Lönnqvist, I. (2004). Completed Suicide after a Suicide Attempt: A 37-Year Follow-Up Study. American Tournal of Psychiatry, 161(3), 562-563. https://doi. org/10.1176/appi.aip.161.3.562

Van Orden, K. A., Smith, P. N., Chen, T., \& Conwell, Y. (2016). A Case Controlled Examination of the Interpersonal Theory of Suicide in the Second Half of Life. Archives of Suicide Research, 20(3), 323-335. https://doi.org/10.1 080/13811118.2015.1025121

Van Orden, K. A., Witte, T. K., Cukrowicz, K. C., Braithwaite, S. R., Selby, E. A., \& Joiner, T. E. (2010). The interpersonal theory of suicide. Psychological Review, 117(2), 575-600. https://doi.org/10.1037/a0018697

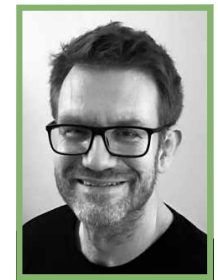

JOHAN SIQVELAND er psykologspesialist og spesialrådgiver i selvmordsforebyggende arbeid ved Akershus Universitetssykehus HF og ph.d.-kandidat ved Det medisinske fakultet, UiO. Han jobber til daglig med implementering av selvmordsforebyggende tiltak gjennom undervisning og fagutvikling. 